\title{
Hubungan Antara Usia Menarche dan Riwayat Penggunaan Alat Kontrasepsi dengan Menopause Dini pada Lansia di Desa Dukuh Indramayu
}

\section{The Relationship between Menarche Age and History of Contraceptive Use With Early Menopause in the Elderly in Dukuh Village Indramayu}

\author{
Tutin Marlia \\ Akper Saifuddin Zuhri Indramayu \\ Email: marliatutin@yahoo.com
}

\begin{abstract}
Abstrak
Waktu terjadinya menopause pada setiap wanita berbeda-beda, sebagian besar wanita mengalami menopause secara alamiah yaitu menopause yang terjadi seiring dengan bertambahnya usia dan akibat dari penurunan organ reproduksi. Rata-rata usia menopause terjadi pada usia 51,4 tahun. Banyak faktor yang berhubungan dengan terjadinya menopause. Beberapa faktor tersebut yaitu usia pertama kali mendapat haid (menarche), stres, pemakaian metode kontrasepsi, status keluarga (seperti status perkawinan, jumlah anak dan usia saat melahirkan anak terakhir), riwayat keluarga, pekerjaan, pendapatan, merokok, dan minum alkohol. Berdasarkan studi pendahuluan yang dilakukan oleh peneliti dengan cara mewawancarai 10 orang didapatkan data bahwa, 6 diantaranya sudah menopause, 4 belum menopause. Dari 6 orang yang sudah menopause tersebut 2 diantaranya mengalami menopause sebelum usia 40 tahun. 4 dari 10 lansia tersebut pernah melahirkan lebih dari 5x, 4 orang pernah melahirkan sebanyak 3x dan 2 orang pernah melahirkan 2x. 10 dari lansia tersebut 8 orang diantaranya menggunakan alat kontrasepsi hormonal dan 2 orang menggunakan alat kontrasepsi non hormonal. Penelitian ini bertujuan untuk mengetahui Hubungan Antara Usia Menarche dan Riwayat Penggunaan Alat Kontrasepsi Dengan Menopause Dini. Jenis Penelitian yang digunakan dalam penelitian ini adalah kuantitatif dengan desain survei analitik dengan menggunakan rancangan cross sectional. Tehnik sampling dalam penelitian menggunakan total samplingberjumlah 57 responden. Hasil penelitian Terdapat hubungan yang signifikan dari faktor usia menarche dengan menopause dini dengan nilai p 0.007 dan tidak terdapat hubungan antara riwayat penggunaan alat kontrasepsi dengan menopause dini dengan nilai p 0.98. Penelitian ini masih terbatas, perlu adanya pengembangan dan pendalaman dalam menganalisis setiap variabelnya ataupun perlu menambah dengan variabel lain. Begitupun variabel lain yang dapat diteliti misalkan riwayat aktivitas, status gizi, riwayat melahirkan anak pertama dan lain-lain.Penelitian ini dilakukan pada lansia yang dapat memungkinkan ingatan lansia mengalami penurunan, sehingga untuk mendapatkan informasi yang akurat perlu melibatkan anggota keluarga.
\end{abstract}

Kata Kunci: Menopause, lansia

\begin{abstract}
The time of menopause for each woman is different. Most women experience menopause naturally, namely menopause that occurs due to the increase of age and decreasing reproductive organs. The average age of menopause occurs at the age of 51.4 years. Many factors are associated with the occurrence of menopause. Some of these factors are age at first menstruation (menarche), stress, use of contraceptive methods, family status (such as marital status, number of children and age at last childbearing), family history, occupation, income, smoking, and drinking alcohol. Based on a preliminary study conducted by the researcher by interviewing ten people, it was found that 6 of them had menopause, and 4 had not menopause. Thus, six people who had menopause, 2 of them experienced menopause before the age of 40 years. 4 of the ten elderly have given birth more than five times, four people have given birth three times, and two people have given birth two times. In addition, 10 of the elderly, 8 of them used hormonal contraception, and 2 used non-hormonal contraception. This study aims to determine the relationship between the age of menarche and the history of contraceptive use with early menopause. The type of research used in this study is quantitative with an analytical survey design using a cross-sectional design. The sampling technique in this study uses a total sampling of 57 respondents. The study results showed a significant relationship between the age factor of menarche and early menopause with a p-value of 0.007 , and there is no relationship between the history of contraceptive use and early menopause with a p-value of 0.98 . This research is still limited; there needs to be developed and deepening to analyze each variable or add other variables. Likewise, other variables that can be studied include activity history, nutritional status, history of giving birth to their first child, and others. This research was conducted on the elderly, which can allow the memory of the elderly to decrease, so to get accurate information, it is necessary to involve family members.
\end{abstract}

Keywords: Menopause, elderly 


\section{Pendahuluan}

Sasaran pembangunan kesehatan 2025 adalah menjadikan usia harapan hidup orang Indonesia 73,7 persen per tahun. Seiring dengan peningkatan usia harapan hidup tentunya akan berpengaruh terhadap bertambahnya lansia dan keadaan menopause. Kesehatan wanita harus mendapat perhatian, karena pada perjalanan usia sekitar 45 tahun kaum wanita akan mengalami penuaan indung telur sehingga tidak mampu memenuhi hormon estrogen dan sistem hormonal seluruh tubuh yang akan berpengaruh pada perubahan fisik dan fisikologis wanita. ${ }^{1}$

Siklus kehidupan manusia normal dimulai dari bayi, kanak-kanak, remaja, dewasa sampai pada lanjut usia. Wanita melalui siklus hidup normal seiring dengan mengalami fase perkembangan fungsi organ reproduksi. Bertambahnya jumlah orang lanjut usia sebanding dengan bertambahnya wanita menopause. Seorang wanita secara normal akan mengalami menarche pada usia 11-15 tahun, dengan rata-rata menarche 13 tahun, masa reproduksi usia 15-46 tahun, dan menopause usia 50-51 tahun. Wanita Indonesia dengan wanita di Negara Barat dan Asia mengalami menopause di usia yang relatif sama yaitu sekitar 50 tahun. ${ }^{2,3}$

Menjadi tua adalah suatu proses yang merupakan bagian dari kehidupan seseorang, dan sudah terjadi sejak konsepsi dalam kandungan yang berlangsung terus sepanjang kehidupan. Usia lanjut mengandung pengertian adanya perubahan yang progresif pada organisme yang telah mencapai kemasakan, perubahan ini bersifat umum dan irreversible (tidak dapat kembali). ${ }^{3}$

Seorang wanita yang telah menginjak usia diatas 45 tahun akan mengalami proses penuaan yang dimulai dari indung telur sehingga produksi hormone estrogen berkurang yang berakibat berhentinya menstruasi untuk selamanya. ${ }^{4}$ Hormon estrogen yang dibutuhkan oleh tubuh mengalami penurunan, sehingga tubuh mengalami ketidakseimbangan hormone yang berdampak pada perubahan psikologis dan fisik seorang wanita. Semua perubahan yang terjadi ini disebut dengan istilah menopause. ${ }^{5}$

Studi epidemiologis yang dilakukan diberbagai negara mengungkapkan fenomena yang menunjukan fakta bahwa usia menopause di belahan dunia akhir-akhir ini semakin cepat. Didapati rata-rata usia menopause wanita di Amerika Serikat adalah 47,5 tahun. Pada wanita di negara-negara lain seperti Paraguay, Colombia, Italia dan negara-negara di Asia seperti Korea, Jepang, Malaysia termasuk Indonesia rata-rata usia menopause wanita menjadi lebih awal, yaitu sekitar 46,9 tahun. Berdasarkan fakta yang ditemukan dapat disimpulkan bahwa rata-rata usia menopause pada wanita cenderung lebih cepat, seiring dengan berkembangnya zaman. $^{6}$

Jumlah wanita yang berusia 45-55 tahun mencapai 14,3 juta orang. Pada tahun 2017 jumlah penduduk di Indonesia mencapai 261,89 juta orang yang terdiri dari 130,31 juta perempuan dengan jumlah perempuan yang berusia 45-55 tahun dan jumlah wanita dengan umur menopause diperkirakan 15,8 juta orang. Pada tahun 2020 di Indonesia 30,3 juta wanita menopause. ${ }^{7}$ Begitu juga di Provinsi Jawa Barat, jumlah wanita menopause meningkat setiap tahun dengan jumlah tercatat 13,01 juta orang penduduk wanita Jawa Barat dari total penduduk Indonesia yaitu 261,89 juta jiwa. $^{8}$

Rata-rata wanita yang berada di kota besar seperti Jakarta mengalami menopause pada akhir usia 40 tahun atau awal 50 tahun. Penelitian terbaru menyatakan 1 dari 16 wanita berisiko mengalami menopause dini. Jika menopause dini merupakan menopause yang terjadi sebelum usia 40 tahun, maka menopause yang terjadi sebelum usia 45 tahun dianggap sebagai menopause yang cepat. Dikatakan terlamba apabila menopause dialami wanita pada usia $>55$ tahun. ${ }^{9}$

Waktu terjadinya menopause pada setiap wanita berbeda-beda, sebagian besar wanita mengalami menopause secara alamiah yaitu menopause yang terjadi seiring dengan bertambahnya usia dan akibat dari penurunan organ reproduksi. Rata-rata usia menopause 
terjadi pada usia 51,4 tahun. Untuk negara industri, secara umum terjadi pada usia 40 - 58 tahun, tetapi ada juga sebagian dari wanita yang sudah mengalami menopause sebelum usia 40 tahun yang disebut dengan premature menopause atau sering juga disebut dengan menopause dini. Menopause dapat dipengaruhi oleh faktor genetik, merokok, pengangkatan ovarium, dan kemoterapi. ${ }^{10}$

Banyak faktor yang berhubungan dengan terjadinya menopause. Beberapa faktor tersebut yaitu usia pertama kali mendapat haid (menarche), stres, pemakaian metode kontrasepsi, status keluarga (seperti status perkawinan, jumlah anak dan usia saat melahirkan anak terakhir), riwayat keluarga, pekerjaan, pendapatan, merokok, dan minum alkohol. Selain itu, ada juga beberapa faktor lain diantaranya polusi air/udara, pengaruh toksin patogen atau radiasi, perilaku gaya hidup modern, kebiasaan diet, olahraga, pengaruh matahari, perilaku seksual, dan gangguan mental. ${ }^{11}$

Penelitian yang dilakukan Senolinggi bahwa seorang wanita yang mengalami menarche lambat akan mengalami menopause lebih cepat. Hal ini berkaitan dengan produksi hormon estrogen pada wanita tersebut. ${ }^{12}$ Hanasiwi mengatakan bahwa wanita yang tidak memakai kontrasepsi non hormon cenderung menopause lebih cepat karena tidak mendapatkan suplai hormon dari kontrasepsi tersebut. ${ }^{13}$ Menurut Kumalasari Penggunaan alat kontrasepsi terutama kontrasepsi jenis hormonal bekerja dengan cara menekan fungsi indung telur sehingga tidak memproduksi sel telur. Sehingga pada wanita yang menggunakan kontrasepsi ini akan lebih lama atau lebih tua memasuki menopause. ${ }^{4}$

Penelitian ini akan dilakukan di Desa Dukuh, Desa Dukuh adalah salah satu desa yang ada diwilayah kerja Puskesmas Plumbon Kabupaten Indramayu. Penelitian ini lebih tepatnya akan dilakukan pada lansia yang tergabung dalam majlis ta'lim Arrahman Desa Dukuh. Berdasarkan studi pendahuluan yang dilakukan oleh peneliti dengan cara mewawancarai 10 orang didapatkan data bahwa, 6 diantaranya sudah menopause, 4 belum menopause. Dari 6 orang yang sudah menopause tersebut 2 diantaranya mengalami menopause sebelum usia 40 tahun. 4 dari 10 lansia tersebut pernah melahirkan lebih dari $5 \mathrm{x}, 4$ orang pernah melahirkan sebanyak $3 x$ dan 2 orang pernah melahirkan $2 x$. 10 dari lansia tersebut 8 orang diantaranya menggunakan alat kontrasepsi hormonal dan 2 orang menggunakan alat kontrasepsi non hormonal.

Tujuan dilakukannya penelitian ini adalah untuk mengetahui hubungan antara usia menarche dan riwayat penggunaan alat kontrasepsi dengan menopause dini pada lansia di Desa Dukuh Indramayu.

\section{Metode Penelitian}

Jenis Penelitian yang digunakan dalam penelitian ini adalah kuantitatif dengan desain survei analitik dengan menggunakan rancangan cross sectional.Tehnik sampling dalam penelitian menggunakan total sampling pada seluruh lansia yang tergabung dalam Jamaah Majlis Talim Arrahman di Desa Dukuh dengan jumlah 57 orang. Tehnik pengumpulan data menggunakan instrumen jenis kuisioner. Analisa data menggunakan jenis univariat dan bivariat dengan menggunakan uji Chi square.

\section{Hasil}

Berikut ini adalah analisis hasil penelitian yang ditampilkan dalam bentuk tabel yang menggambarkan distribusi frekuensi dari masing-masing variabel, hubungan antar variabel dan variabel yang diteliti. 


\section{a. Analisis Univariat}

1. Distribusi Frekuensi Usia Menarche Responden

Tabel 1. Distribusi Frekuensi usia Menarche Pada Lansia di Desa Dukuh Kabupaten Indramayu Tahun 2021

\begin{tabular}{lcc}
\hline \multicolumn{1}{c}{ Usia Responden } & Frekuensi (n) & Presentase \% \\
\hline$\leq 14$ tahun & 22 & 38.6 \\
$>14$ tahun & 35 & 61.4 \\
Total & $\mathbf{5 7}$ & $\mathbf{1 0 0}$ \\
\hline
\end{tabular}

Berdasarkan tabel 1 dapat dijelaskan bahwa umur responden/lansia saat menstruasi pertama/menarche terbanyak adalah di usia $>14$ tahun yaitu 35 orang $(61.49 \%)$.

2. Distribusi Frekuensi Usia Menarche

Tabel 2. Distribusi Frekuensi Responden Yang Menggunakan Alat Kontrasepsi di Desa Dukuh Kabupaten Indramayu Tahun 2021

\begin{tabular}{lcc}
\hline \multicolumn{1}{c}{ Alat Kontrasepsi } & Frekuensi (n) & Presentase \% \\
\hline Hormonal & 40 & 70.2 \\
Non Hormonal & 17 & 29.8 \\
Total & $\mathbf{5 7}$ & $\mathbf{1 0 0}$ \\
\hline
\end{tabular}

Berdasarkan tabel 2 dapat dijelaskan bahwa lansia yang memiliki riwayat menggunakan alat kontrasepsi terbanyak adalah dengan metode hormonal yaitu 40 responden $(70.2 \%)$.

\section{b. Analisi Bivariat}

1. Hubungan Antara menarche responden Dengan Menopause Dini

Tabel 3. Hubungan Antara Usia Menarche Responden Dengan Menopause Dini Pada Lansia di Desa Dukuh Kabupaten Indramayu Tahun 2021

\begin{tabular}{|c|c|c|c|c|c|c|c|}
\hline \multirow{3}{*}{$\begin{array}{l}\text { Usia } \\
\text { Menarche }\end{array}$} & \multicolumn{4}{|c|}{ Menopause } & \multicolumn{2}{|c|}{ Total } & \multirow[t]{3}{*}{ Nilai $p$} \\
\hline & \multicolumn{2}{|c|}{ Menopause Dini } & \multicolumn{2}{|c|}{$\begin{array}{c}\text { Tidak Menopause } \\
\text { Dini }\end{array}$} & $\mathrm{N}$ & $\%$ & \\
\hline & $\mathrm{N}$ & $\%$ & $\mathrm{~N}$ & $\%$ & & & \\
\hline $\begin{array}{l}\leq 14 \\
\text { tahun }\end{array}$ & 19 & 86.36 & 3 & 13.63 & 22 & 100 & 0.007 \\
\hline $\begin{array}{l}>14 \\
\text { tahun }\end{array}$ & 18 & 51.42 & 17 & 48.57 & 35 & 100 & \\
\hline
\end{tabular}

Berdasarkan tabel 3 dapat dijelaskan bahwa responden yang memilki usia menarche $\leq$ 14 tahun memiliki prosentasi terbanyak mengalami menopause dini yaitu sebanyak $(86.36 \%)$, untuk usia menarche responden $>14$ tahun mengalami menopause dini sebanyak $(51,42 \%)$. Berdasarkan hasil hitung Chi Square didapatkan angka p 0.007 yang berarti terdapat hubungan yang signifikan antara usia menarche responden dengan menopause dini pada lansia di Desa Dukuh Kabupaten Indramayu. 


\section{Hubungan Antara Riwayat Penggunaan Alat Kontrasepsi Dengan Menopause Dini}

Tabel 4. Hubungan Antara Riwayat Penggunaan Alat Kontrasepsi Dengan Menopause Dini Pada Lansia di Desa Dukuh Kabupaten Indramayu Tahun 2021

\begin{tabular}{|c|c|c|c|c|c|c|c|}
\hline \multirow{3}{*}{$\begin{array}{l}\text { Riwayat } \\
\text { Penggunaan Alat } \\
\text { Kontrasepsi }\end{array}$} & \multicolumn{4}{|c|}{ Menopause } & \multicolumn{2}{|c|}{ Total } & \multirow[t]{3}{*}{ Nilai $\mathrm{p}$} \\
\hline & \multicolumn{2}{|c|}{$\begin{array}{l}\text { Menopause } \\
\text { Dini }\end{array}$} & \multicolumn{2}{|c|}{$\begin{array}{l}\text { Tidak Menopause } \\
\text { Dini }\end{array}$} & \multirow[t]{2}{*}{$\mathrm{N}$} & \multirow[t]{2}{*}{$\%$} & \\
\hline & $\mathrm{N}$ & $\%$ & $\mathrm{~N}$ & $\%$ & & & \\
\hline Hormonal & 26 & 65 & 14 & 35 & 40 & 100 & \multirow[t]{2}{*}{0.983} \\
\hline Non Hormonal & 11 & 64.7 & 6 & 35.29 & 17 & 100 & \\
\hline
\end{tabular}

Berdasarkan tabel 4 dapat dijelaskan bahwa dari 57 responden yang memiliki riwayat penggunaan alat kontrasepsi hormonal lebih banyak yang mengalami menopause dini $(65 \%)$, responden yang memiliki riwayat penggunaan alat kontrasepsi non hormonal juga lebih banyak mengalami menopause dini (64.7\%). Berdasarkan hasil hitung Chi Square didapatkan angka p 0.983 yang berarti tidak terdapat hubungan antara riwayat penggunaan alat kontrasepsi dengan menopause dini pada lansia di Desa Dukuh Kabupaten Indramayu.

\section{Pembahasan}

\section{a. Hubungan Antara Usia Menarche Dengan Menstruasi Dini}

Hasil penelitian menyatakan bahwa usia menarche atau menstruasi pertama pada $>14$ tahun yaitu $61.4 \%$, sebagian lagi mengalami menarche di usia $\geq 14$ tahun yaitu $38.6 \%$. Berdasarkan hasil hitung uji statistik Chi Square didapatkan angka p 0.007 yang berarti terdapat hubungan yang signifikan antara usia menarche responden dengan menopause dini pada lansia di Desa Dukuh Kabupaten Indramayu.

Hasil dari penelitian ini dapat diketahui bahwa sebagian besar responden mengalami usia menarche $\leq 14$ tahun dan mengalami menopause dini . Hal ini dipengaruhi oleh beberapa faktor, salah satunya adalah nutrisi. Seseorang yang mempunyai nutrisi baik, akan mengalami menarche lebih cepat karena nutrisi mempengaruhi pembentukan lemak tubuh yang secara tidak langsung akan terjadi metabolisme lemak oleh beberapa hormon yaitu hormon estrogen. Hormon ini adalah hormon yang membantu dalam pertumbuhan dan perkembangan remaja. Seseorang yang mengalami menarche lebih cepat, mempunyai masa reproduksi yang panjang karena AMH yang tinggi sehingga terjadi menopause yang lebih lama. ${ }^{14}$

Menopause adalah haid terakhir pada wanita yang juga sering diartikan sebagai berakhirnya fungsi reproduksi seorang wanita. Oleh karena itu, tidak jarang seorang wanita takut menghadapi saat menopausenya. Menopause dikenal sebagai berhentinya menstruasi yang disebabkan oleh hilangnya aktifitas folikel ovarium. Menopause alamiah terjadi pada akhir periode menstruasi dan sekurang-kurangnya selama 12 bulan tidak mengalami menstruasi (amenorea), dan bukan disebabkan oleh hal yang patologis. Hal ini disebabkan karena pembentukan hormon estrogen dan progesteron dari ovarium wanita berkurang, ovarium berhenti melepaskan sel telur sehingga aktivitas menstruasi berkurang dan akhirnya berhenti sama sekali. Sebahagian wanita memasuki usia 50 tahun dan menjadi tua seringkali menjadi momok yang menakutkan. Kekhawatiran ini berawal dari pemikiran bahwa dirinya akan menjadi tidak sehat, tidak bugar, dan tidak cantik lagi, kondisi tersebut memang tidak menyenangkan dan menyakitkan. Padahal, masa tua dan menopause merupakan salah satu tahap yang harus dijalani seorang wanita dalam kehidupannya. Seperti halnya tahap-tahap kehidupan yang lain, yaitu masa anakanak dan masa reproduksi. Namun munculnya rasa kekhawatiran yang berlebihan itu menyebabkan mereka sangat sulit menjalani masa ini. ${ }^{15}$ 
Penelitian ini sejalan dengan penelitian yang dilakukan oleh Mutiara, dkk bahwa terdapat hubungan antara usia menarche dengan usia menopause pada wanita, makin dini menarche terjadi makin lambat menopause timbul dan sebaliknya. Semakin dini seorang wanita mengalami menarche maka semakin lambat ia mengalami menopause. Sebaliknya, semakin lambat mengalami menarche maka semakin dini mengalami menopause. ${ }^{16}$ Penelitian ini sesuai dengan teori Kasdu yang mengatakan bahwa ada hubungan antara usia pertama kali mendapat haid dengan usia seseorang wanita memasuki menopause. Semakin muda seseorang mengalami haid pertama kalinya, semakin tua atau lama ia memasuki usia menopause. ${ }^{9}$ Penelitian ini juga sejalan dengan hasil penelitian Rohmatika ada pengaruh usia menarche terhadap usia menopause pada wanita menopause. ${ }^{17}$

Usia remaja yang mendapat menarche bervariasi yaitu antara usia 10-16 tahun, tetapi rata-rata 12,5 tahun, antara 11-15 tahun. Dengan penggolongan : Menarche dini yaitu usia 10-11 tahun, menarche normal yaitu usia 11-15 tahun, dan menarche terlambat yaitu usia $>15$ tahun. ${ }^{17}$ Adanya variasi saat mengalami haid pertama pada seorang wanita dipengaruhi oleh banyak faktor, antara lain faktor hormonal, genetik, bentuk badan, status gizi, lingkungan, aktivitas fisik dan rangsangan psikis. ${ }^{19}$

Wanita yang mengalami menarche pada usia lebih cepat memiliki jumlah Anti Mullerian Hormone (AMH) yang lebih tinggi dibandingkan dengan wanita yang mengalami menarche pada usia yang lebih lambat. ${ }^{20}$. Semakin muda seseorang mengalami haid pertama kalinya, semakin lama ia memasuki masa menopause, sehingga masa reproduksi makin panjang. ${ }^{20}$ Wanita yang mengalami menarche pada usia lebih cepat memiliki jumlah Anti Mullerian Hormone $(\mathrm{AMH})$ yang lebih tinggi dibandingkan dengan wanita yang mengalami menarche pada usia yang lebih lambat. AMH disekresikan oleh sel-sel granulosa dalam pertumbuhan folikel ovarium primer, sekunder dan antral dengan sekresi tertinggi terdapat pada tahap sekunder dan antral, kemudian berakhir dengan pertumbuhan folikel lanjut. Tingkat AMH rendah pada saat lahir, meningkat pada masa kanak-kanak dan puncaknya pada saat remaja, kemudian menurun secara bertahap berdasarkan usia. Namun, terdapat wanita yang terjadi menopause dini walaupun usia menarchenya lebih awal, kemungkinan faktor penyebabnya adalah aktifitas fisik. Aktivitas yang tinggi dapat mempengaruhi ovarium menjadi terbatas dengan mengurangi serum estrogen dan meningkatkan hormon seks globulin yang dapat menyebabkan menopause lebih cepat ${ }^{20}$.

Adanya beberapa faktor yang mempengaruhi usia menopause menyebabkan perbedaan saat terjadinya menopause antara wanita yang satu dengan wanita lainnya. Faktor-faktor tersebut antara lain usia saat haid pertama (menarche), beban pekerjaan, status perkawinan, jumlah anak, usia saat melahirkan anak terakhir, penggunaan kontrasepsi, kebiasaan merokok, kebiasaan mengonsumsi alkohol, serta adanya riwayat penyakit tertentu yang berhubungan dengan organ reproduksi. ${ }^{17}$

Adapun pendapat lain dari Speroff dan Reitz bahwa wanita yang terlambat mendapatkan menstruasi, pada usia 16 atau 17 tahun, justru akan mengalami menopause lebih dini, sedangkan mereka yang haid lebih dini seringkali akan mengalaminya sampai pada usia mencapai 50 tahun. Ada pola keluarga yang berlaku secara umum, bagi seorang wanita yang ibu atau kakak perempuannya lebih dini mengalami menopause maka ia juga cenderung mengalami hal yang sama, begitu pula sebaliknya. ${ }^{20}$

\section{b. Hubungan Antara Riwayat Penggunaan Alat Kontrasepsi Dengan Menopause Dini}

Berdasarkan hasil penelitian dapat dijelaskan bahwa 70.2\% responden menggunakan jenis alat kontrasepsi hormonal berupa pil, suntik, IUD dan implan, Berdasarkan hasil hitung Chi Square didapatkan angka p 0.983 yang berarti tidak terdapat hubungan antara riwayat penggunaan alat kontrasepsi dengan menopause dini. Secara pengertian, 
kontrasepsi adalah alat atau obat yang tujuannya untuk menjarangkan kehamilan. Orangorang yang menggunakan kontrasepsi adalah pasangan yang berniat untuk membatasi jumlah anak dan menjarangkan kehamilan. ${ }^{22}$ Jenis kontrasepsi dibagi menjadi dua yaitu kontrasepsi non hormonalyang merupakan alat kontrasepsi yang tidak mengandung hormon. Sehingga, penggunaannya tidak mempengaruhi kondisi hormonal dalam tubuh, sedangkan kontrasepsi hormonal memiliki tujuan untuk mencegah terjadinya kehamilan yang dapat bersifat sementara dan permanen. ${ }^{3}$

Kandungan hormon estrogen dan progesteron yang ada pada kontrasepsi hormonal berdampak pada perubahan hormonal pada ovarium, Karena tubuh terus menerus diberikan maka merangsang hipofisis tidak memproduksi kedua hormon tersebut sehingga hormon estrogen dan progesteron tidak diproduksi. Perubahan hormone tersebut menyebabkan perubahan haid, ada yang tidak teratur bahkan ada yang mundur, seperti diketahui menstruasi terjadi karena adanya hormone estrogen dan progesterone yang secara stimulant merangsang pembentukan endometrium. Pembentukan hormone-hormone tersebut dilakukan oleh kedua indung telur. Perangsangan dari terbentuknya hormone tersebut karena adanya FSH (folikel stimulating hormone) dan LH (luteinizing hormone). Pengaruh negative dari ketidakseimbangan hormon tersebut bisa menyebabkan mundurnya siklus menstruasi. ${ }^{21}$

Hal ini sejalan dengan teori berikut bahwa Pada pemakaian alat kontrasepsi hormonal, mengandung kombinasi hormon yaitu estrogen dan progesteron yang cara kerjanya menekan fungsi indung telur sehingga tidak memproduksi sel telur maka tidak terjadi pengurangan sel telur mengakibatkan masa menopause lebih panjang sampai sel telur habis dan menyebabkan menopause lebih lama atau tua. ${ }^{22}$ Hasil penelitian dapat diketahui bahwa sebagian besar adalah ibu menggunakan kontrasepsi hormonal. Seorang perempuan yang menggunakan kontrasepsi hormon, tidak terjadi pengurangan sel telur sehingga terjadi menopause yang lama. Hal ini sependapat dengan penelitian Fibrilla dkk bahwa wanita dengan riwayat penggunaan kontrasepsi hormon mengakibatkan kerja hormon tersebut menekan indung telur sehingga sel telur tidak diproduksi dan berpengaruh pada keterlambatan seorang wanita memasuki masa menopause. ${ }^{23}$

\section{Kesimpulan dan Saran}

\section{Kesimpulan}

1. Distribusi usia menarche responden adalah $\leq 14$ sebanyak $38 \%$ dan $>14$ tahun sebanyak $61.4 \%$

2. Distribusi frekuensi riwayat penggunaan alat kontrasepsi adalah riwayat pengguna kontrasepsi hormonal $70.2 \%$ dan kontrasepsi non hormonal $29.8 \%$

3. Terdapat hubungan yang signifikan dari faktor usia menarche dengan menopause dini dengan nilai $\mathrm{p} 0.007$

4. Tidak terdapat hubungan antara riwayat penggunaan alat kontrasepsi dengan menopause dini dengan nilai $\mathrm{p} 0.983$

\section{Saran}

Penelitian ini masih terbatas, perlu adanya pengembangan dan pendalaman dalam menganalisis setiap variabelnya ataupun perlu menambah dengan variabel lain. Begitupun variabel lain yang dapat diteliti misalkan riwayat aktivitas, status gizi, riwayat melahirkan anak pertama dan lain-lain. 
Penelitian ini dilakukan pada lansia yang dapat memungkinkan ingatan lansia mengalami penurunan, sehingga untuk mendapatkan informasi yang akurat perlu melibatkan anggota keluarga.

\section{Daftar Pustaka}

1. Manuaba, I, B., 2010, Ilmu Kebidanan, Penyakit Kandungan dan Keluarga Berencana, Jakarta : Salemba Medika

2. Syafruddin, H, 2009, Kebidanan komunitas. Jakarta: EGC

3. Prawiroharjo S, 2011, Ilmu kandungan, Jakarta: PT. Bina Pustaka

4. Kumala Sari, I dan Andyantoro, 2017, Kesehatan Reproduksi untuk Mahasiswa Kebidanan \& Keperawatan, Jakarta: Salemba Medika

5. Wahyunita, V, D dan Fitrah. 2010. "Memahami Kesehatan Pada Lansia”. Jakarta: Trans Info Media.

6. Pradana, 2010. Hubungan Jumlah Paritas dengan Usia Menopause di Kelurahan Tanjung Selamat, Kota Medan. Fakultas Kedokteran Univeritas Sumatra Utara. Skripsi. 2010. http://www.respository.usu.ac.id.

7. Badan Pusat Statistik. 2017. Proyeksi Penduduk Indonesia 2005-2025. Jakarta: Badan Pusat Statistik.

8. Depkes, RI. 2017. Profil kesehatan Indonesia 2017. http://depkes.go.id. Jakarta: Kementerian Kesehatan Republik Indonesia.

9. Nurlaila, R., 2014, Pengaruh peran suami dan persepsi diri terhadap kesiapan psikologi dalam dalam menghadapi klimakterium di Desa Lampaseh kota Banda Aceh.

10. Kusmiran E, 2011, Reproduksi Remaja dan Wanita, Jakarta Salemba Medika

11. Prawiroharjo S, 2007, Ilmu Kandungan. Jakarta: Tridasa Printer.

12. Senolinggi MA. 2014. Hubungan Antara Usia Menarche Dengan Usia Menopause Pada Wanita Di Kecamatan Kakas Sulawesi Utara. Jurnal eClinic (eCl), Volume 3, Nomor 1, Januari-April 2015 https://ejournal.unsrat.ac.id/index.php/eclinic/article/view/6754/6278

13. Hanasiwi, Isa, M., \& Pertiwi, H., W, 2015, Hubungan Paritas dan Pemakaian KB Hormonal dengan Usia Menopause. Jurnal Kebidanan. Vol 7. No 2 Hal 115-222.

14. Safira, A., 2015, Faktor-Faktor yang Berhubungan Dengan Usia Menopause di RW 01 Kelurahan Utan Kayu Utara Jakarta Timur, Skripsi, Fakultas Kesehatan Masyarakat, UIN Jakarta

15. Walyani, E, S dan Purwoastuti, E., 2015. Paduan Materi Kesehatan Reproduksi dan Keluarga Berencana.Yogyakarta : PT. Pustaka Baru Press

16. Mutiara dkk, 2014, Hubungan Antara Usia Menarche Dengan Usia Menopause Pada Wanita di Kecamatan Kakas. Jurnal e-Clinic (eCl), Volume 3, Nomor 1, Januari-April 2015

17. Rohmatika D, Sumarni, P, F., 2012, Pengaruh Usia Menarche Terhadap Usia Menopause pada Wanita Menopause di Desa Jingkang Babakan Kecamatan Ajibarang Kabupaten Banyumas Tahun 2012

18. Anggraini MT. 2014. Hubungan antara usia saat timbulnya menarche dengan usia saat terjadinya menopause wanita di Kecamatan Kartasura. http://jurnal.unimus.ac.id/index.php/psn 12012010/article/view/124/105

19. Marmi, 2013, Kesehatan Reproduksi. Yogyakarta: Pustaka Pelajar.

20. Sinsin, L., 2008. Seri kesehatan Ibu dan Anak Masa Kehamilan dan Persalinan. Jakarta : Elex Media Komputindo

21. Masruroh. 2012. Hubungan Antara Penggunaan Kontrasepsi Hormonal Dengan Usia Menopause. Karya Tulis Ilmiah, Fakultas Ilmu Kesehatan Universitas Darul Ulum, Jawa Timur. 
22. Nita, dkk, 2019, Faktor-Faktor Yang Mempengaruhi Kejadian Menopause Dini di Desa Kalirejo, Kecamatan Kalipare Kabupaten Malang, Journal for Quality in Women's Health | Vol. 2 No. 1 March 2019 | pp. 50 - 56 p-ISSN: 2615-6660 | e-ISSN: 2615-6644 DOI: 10.30994/jqwh.v2i1.28 Website: http://jurnal.strada.ac.id/jqwh|Email: jqwh@strada.ac.id 23. Fibrila, F, \& Ridwan, M, 2014, Hubungan Usia Melahirkan Terakhir, Riwayat Pemakaian Kontrasepsi, Menarche dan Budaya dengan Menopause Di Kelurahan Mulyosari Kecamatan Metro Barat. Jurnal Kesehatan Metro Sai Wawai. Vol 7. No 1 Hal 93-101. 